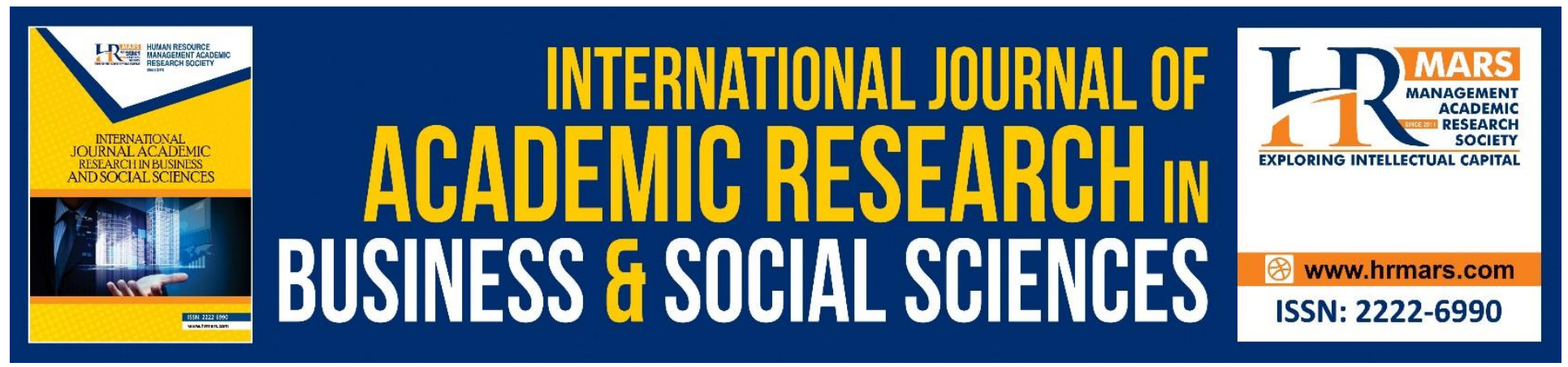

\title{
Development and Validity of TIG Welding Training Modules Based on the Dick and Raiser Model Design in the Subject (DJJ3032) of Mechanical Workshop Practice 3 in Polytechnic Malaysia
}

Che Ghani Che Kob, Md Kharul Bin Rakib, Arman Shah \& Arasinah

To Link this Article: http://dx.doi.org/10.6007/IJARBSS/v8-i11/4921

DOI: $10.6007 /$ IJARBSS/v8-i11/4921

Received: 11 Oct 2018, Revised: 23 Oct 2018, Accepted: 17 Nov 2018

Published Online: 29 Nov 2018

In-Text Citation: (Kob, Rakib, Shah, \& Arasinah, 2018)

To Cite this Article: Kob, C. G. C., Rakib, M. K. Bin, Shah, A., \& Arasinah. (2018). Development and Validity of TIG Welding Training Modules Based on the Dick and Raiser Model Design in the Subject (DJJ3032) of Mechanical Workshop Practice 3 in Polytechnic Malaysia. International Journal of Academic Research in Business and Social Sciences, 8(11), 463-474.

Copyright: @ 2018 The Author(s)

Published by Human Resource Management Academic Research Society (www.hrmars.com)

This article is published under the Creative Commons Attribution (CC BY 4.0) license. Anyone may reproduce, distribute, translate and create derivative works of this article (for both commercial and non-commercial purposes), subject to full attribution to the original publication and authors. The full terms of this license may be seen

at: http://creativecommons.org/licences/by/4.0/legalcode

Vol. 8, No. 11, 2018, Pg. 463 - 474

Full Terms \& Conditions of access and use can be found at http://hrmars.com/index.php/pages/detail/publication-ethics 


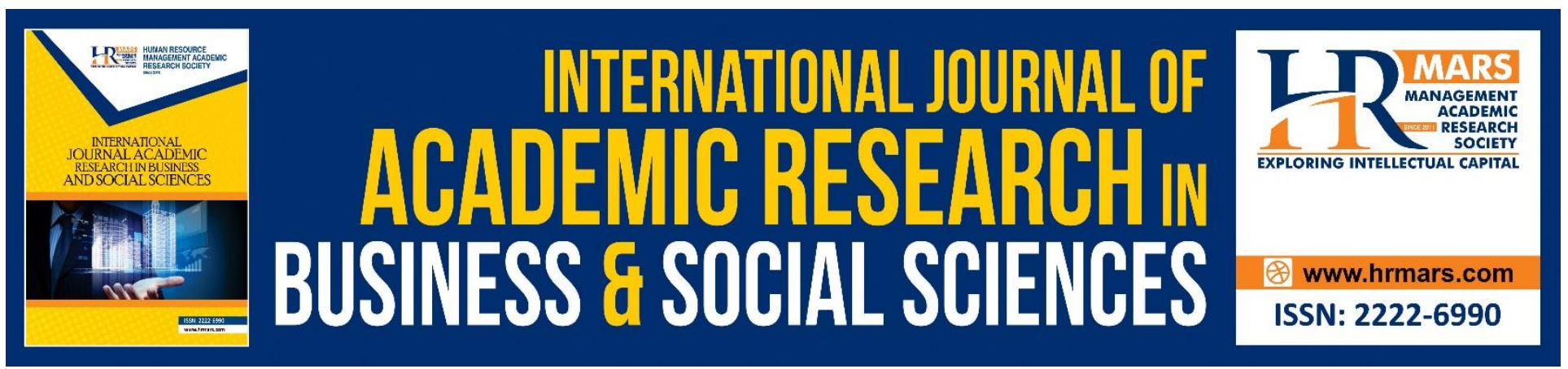

\title{
Development and Validity of TIG Welding Training Modules Based on the Dick and Raiser Model Design in the Subject (DJJ3032) of Mechanical Workshop Practice 3 in Polytechnic Malaysia
}

Che Ghani Che Kob, Md Kharul Bin Rakib, Arman Shah \& Arasinah Department of Engineering Technology, Faculty of Technical and Vocational Education, Universiti Pendidikan Sultan Idris, 35900 Tanjung Malim, Malaysia

\begin{abstract}
This study is aimed at the development of TIG Welding Training Modules based on The Dick and Raiser Model in the Subject (DJJ3032) of Mechanical Workshop Practice 3 in Malaysia Polytechnic. The Dick and Raiser Model has seven steps that must be systematically implemented to produce a robust module and meet the objectives to be achieved. The study was a quantitative approach that used the survey method to obtain an expert opinion through a questionnaire related to the contents of the TIG Welding Training Module. The research sample consists of four experts who are experienced in TIG field in Malaysia Polytechnic. The findings show that this TIG Welding Training Module has a high content of authenticity. Hence, the TIG Welding Training Module is expected to provide exposure and assist polytechnic lecturers towards teaching and learning as well as helping to understand the Malaysian Polytechnic students.
\end{abstract}

Keywords: Development, TIG Welding Training Module, Design, Mechanical Workshop Practice 3 (DJJ3032), Model Dick and Raiser, Validity.

\section{Introduction}

The purpose of this study is to comprehend the development and validity of the TIG Welding Training Modules based on Dick and Raiser Model design in the subject Mechanical Engineering Workshop 3 (DJJ3032) in Malaysia Polytechnic.

This study was conducted because of the absence of a learning module that can help students in learning. In addition, on the monitoring of researchers shows that there are only two studies in the development of the welding module in Malaysia Polytechnic and there is no TIG Welding Module Training in Malaysia Polytechnic or other technical education institutions. The first study by Rubani (2016) was to develop and evaluate the effectiveness of the structured structural mess sets in Project- 
Based Learning (PBP) on the knowledge of machine-operated and the second-line learning by Talib and Saud (2011) in developing a Multimedia Aided Learning (CAL) the basic topics of gas welding based on Theory of Cognitive Load. The welding subject is one of the core subjects for mechanical course students in all KPM Polytechnics and the subject code is DJJ3032 Mechanical Workshop Practice 3. Additionally, this module also emphasizes the process of manufacturing a mechanical engineering product. This illustrates the importance of the Project-Based Learning Module (MPBP) in helping Polytechnic students to succeed in welding courses to achieve the 2050 National Transformation (TN50) goal.

The gas tungsten arc welding (TIG) is an arc welding process that produces a metal connection by heating it with an arc between the steady-state electrode tungsten. The arc breakthrough is obtained by using an inert gas supplied separately, which was the same with the metal arc welding gas. This process is also known as the inert gas process of tungsten. The gases used are argon, helium or a mixture of both.

The learning modules are an instruction package that includes several conception units from a subject that brings the objective towards self-learning for students (Noah \& Ahmad, 2005). In the meantime, the learning modules are defined as an alternative learning in the effort to produce independent, proactive, dynamic and creative students (Ahmad Mokhtar, 2006). In addition, according to Honey and Mumford (1992) studies, "Academic Modules are customizable packages designed to assist educators in creating or supplementing a course syllabus". This means that the learning module is a planned, neat, and systematic package based on the learning scale for example the OBE-based polytechnic learning syllabus. In addition, the learning module also allows students to learn according to their own abilities.

According to the study of Ahmad (2002) the module is a complementary curriculum prepared by lecturers and guides in PdP and is used for self-learning. Additionally, a good module will apply pure values, bringing students to think that they get the maximum benefit from the used of the module. In addition, there are various types of modules such as training modules, learning modules, academic modules and On-line modules. Meanwhile, according to Razak and Rahman (2017) studies, explaining the learning modules are as a source of reference and guidance to student in the learning process. In addition, apart from listening to lectures delivered by lecturers, students also have organized and systematic learning materials to be used as reference materials and their revisions.

The TIG Welding Training Module is a teaching and learning module (PdP) introduced to help students who are weak in learning. Additionally, the teaching and learning modules are more emphasizing on individual teaching where the module-based teaching activities are more focused on students. Meanwhile, each student will be given a module and the student will follow the module according to the instructions given in the module (Noah, 2005).

The construction of the module usually helps the students to master the weak subjects; for instant, the TIG Welding Training Module helps students in the DJJ3032 of Mechanical Workshop 3 in 
Malaysia Polytechnic. However, this module is designed to assist the lecturers in their presentation at the Malaysian Polytechnic. In addition, this module can also facilitate any mechanical lecturer who wants to use the Project Based Learning Method (PBP) as a method of teaching in the lectures.

\section{Learning Background}

The Dick and Reiser Model (1996) was developed to help lecturers to plan the effective teaching by using some of the basic procedures in teaching design. In addition, in this model, there are seven components that can help us to plan a systematic and effective teaching (Refer to figure 1). This model helps researchers in designing the TIG Welding Training Modules. Here are the parts of this model:

Figure 1: Dick and Reiser Model (1996)

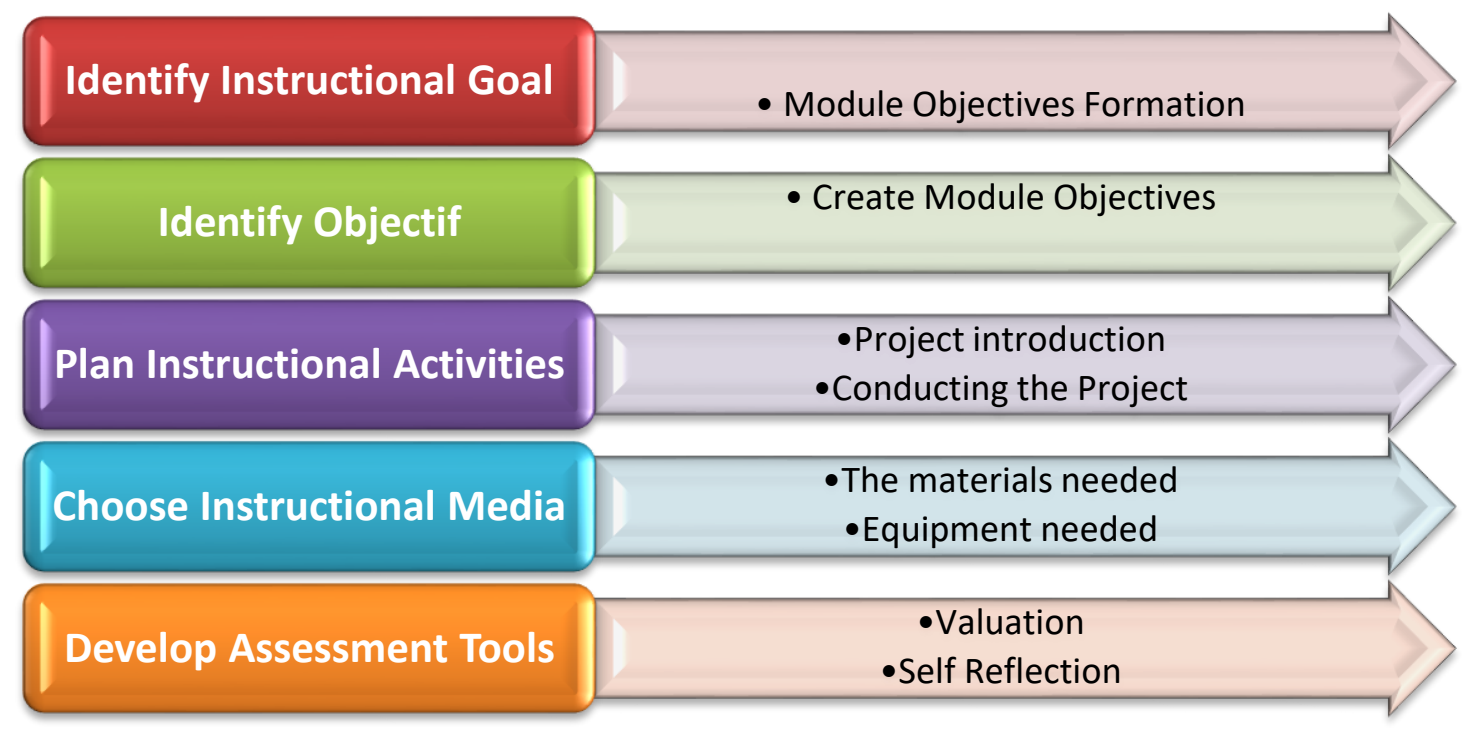

\section{i. Defining Goals}

The first component in this model is to determine the module's objectives. The set of the goal is important to manage the overall development of TIG Welding Training Modules.

\section{ii. Writing Objectives}

The module's objectives are set as learning objectives. Instead of goals, objectives can be written more specifically or shown as learning outcomes using the TIG Welding Training Module.

\section{iii. Build Learning Activities}

Learning activities are built on the goals and objectives. In addition, the Project Based Learning Module (MPBP) in which learning activities have been coordinated using the PBP method where the student's activity is to produce a module based on the project (MPBP) by referring to the module development guide. 


\section{iv. Select and Build Media Teaching}

The teaching media was selected and developed to help the learning process. For this module, the teaching media used is the book and PowerPoint as a guide to students. The video footage per step of project creation can also be selected as a good teaching medium.

\section{v. Implement Teaching}

In this component, the learning process that will be implemented is student-centered. Students will build project modules as required by applying elements of creativity and innovation as well as applying TIG welding skills.

\section{Vi. Build Assessment}

Assessment is important in a learning module. This assessment for the Project Based Learning Module (MPBP) is more focus on assessing the TIG welding skills and assessing the product or artifacts that have been produced. In addition, the required elements in the assessment need to be clearly stated. The MPBP appraisal guide is based on the Malaysian Polytechnic TIG welding evaluation rubrics.

\section{Vii. Reassess Teaching}

The whole process of learning is reviewed and evaluated. The weaknesses that arise during the learning process and disturb to achieve the desired objectives need to be reorganized and require improvement.

\section{Dick and Reiser Model Selection Factor}

The Dick and Reiser Model (1996) was selected as the design model for the development of the TIG Welding Training Module. This is because it is motivated by some interesting and appropriate elements:

i. All information and elements are customizable and easy to customize to meet the curriculum requirements, Subject Matter (DJJ3032) Mechanical Workshop Practice 3 for the third semester at Malaysian Polytechnic.

ii. The modules are suitable for lecturers who want to use the project approach or methodology, especially the new lecturers and trainee lecturers.

iii. All planned and constructed activities are student-centered and lecturers are as monitors or facilitators. This is in line with the TIG Welding Training Modules which are student-centered and lecturers as facilitators in monitoring student learning.

iv. There are elements that discuss the introduction of concepts, discussion of project ideas and examples of using the concept in the actual project module.

v. There is a section where students can apply the concept of TIG welding that has been learned into the daily lives of students.

vi. The activities organized and the selection of learning materials are in line with the level of understanding, simple and interesting to be used by Malaysian Polytechnic students.

vii. There are various forms of assessment to attract students to solve problems in the assessment using the built-in knowledge and module project 
INTERNATIONAL JOURNAL OF ACADEMIC RESEARCH IN BUSINESS AND SOCIAL SCIENCES

Vol. 8, No. 11, Nov, 2018, E-ISSN: 2222-6990 (C) 2018 HRMARS

viii. The implementation of a neatly designed and systematic learning facilitates students and lecturers to use the module.

\section{Research Design}

This study is quantitative using a survey method to identify the validity of the content of the TIG Welding Training Module. The development of modules will have to go through the drafting process to ensure that the modules are built to meet the targets and objectives set. The findings from need analysis, literature review and curriculum reviews are needed during the drafting process of this module. In addition, the module developed, should be reviewed by field experts to obtain the validity of the module content in this study, the authors conduct the validity of the contents of the TIG Welding Training Modules to ensure that the contents of the Modul are built to be accurate and recognized quality.

The use of validity in the study is to test the extent to which the accuracy of a measuring instrument studied in a study. According to Pallant (2007), validity refers to the extent to which a tool used to accurately measure the characteristics studied in a study. This implies that an instrument is considered to be valid and can be applied if it can measure what is supposed to be measured and an instrument or instrument of measurement is also valid when the construction of the tool meets or meets its function and objectives. According to Sidek \& Jamaluddin (2012), modules are also considered as a measurement tool as the module itself is a tool, material and resource which are used as a guide for researchers to get information related to research conducted. According to Md Noor, Nurul Ain and Norazani (2016) states that the validity of the module is refers to the accuracy of the concept and the content of the module.

Meanwhile, according to Othman (2014), the validity process is an indicator for the accuracy of the study; whether the study gives a true picture of the phenomenon studied or not. This validity process should also be done by individuals who are experts in the areas related to the contents of the module. This is in line with Noraini's (2013) statement, which states that in order to increase the validity of the contents of a module, researchers need to obtain views and feedback from experts to evaluate and ensure the elements contained in a module represent the area of the study to be studied. This is because the feedback and views of these experts are very important for getting a quality module that can be used.

For the validity of the module content according to Anastasi and Urbina (1997), the validity of the content is a systematic assessment of the quality of a module's content that measures what should be measured. Additionally, to ensure that the built module is robust and applicable, the percentage of validity of module content should be taken into account. This is because of the high validity of the findings obtained based on facts and able to give precise justification (Noraini, 2013).

\section{Research Population and Sample}

The researcher has provided a complete copy of the TIG Welding Training Module which contains the introduction, objectives and goals of the module, the basis of the theory used, the overall content 
INTERNATIONAL JOURNAL OF ACADEMIC RESEARCH IN BUSINESS AND SOCIAL SCIENCES Vol. 8, No. 11, Nov, 2018, E-ISSN: 2222-6990 @ 2018 HRMARS

and the attachment of the teaching aids. The modules are available for review and evaluation and are provided by a panel of experts. The expert group selection in this study is based on expertise, experience and relevance with the contents of the module developed. In this study, the criteria for specialist selection are based on (i) expertise and knowledge in the field of TIG / GTAW welding. (ii) Expertise and experience in the field of welding (iii) expertise and experience in language and (IV) experienced practitioners or welders. Experienced practitioners or lecturers in the field of welding are further defined by ensuring that they understand and implement teaching and learning in Malaysian Polytechnic. The list of expert panels is like table 1 below.

Table 1: Expert Panel Profiles

\begin{tabular}{|l|l|l|}
\hline Expert & Qualification & Expertise / experience \\
\hline Expert 1 & $\begin{array}{l}\text { Malaysian } \\
\text { Polytechnic } \\
\text { Lecturer }\end{array}$ & Experienced teaching welding over 25 years \\
\hline Expert 2 & $\begin{array}{l}\text { Malaysian } \\
\text { Polytechnic } \\
\text { Lecturer }\end{array}$ & $\begin{array}{l}\text { Experienced teaching welding more than } 10 \text { years and has been a } \\
\text { manufacturer for welding courses at community colleges. }\end{array}$ \\
\hline Expert 3 & $\begin{array}{l}\text { Malaysian } \\
\text { Polytechnic } \\
\text { Lecturer }\end{array}$ & Teaching welding courses for about 13 years \\
\hline Expert 4 & $\begin{array}{l}\text { Malaysian } \\
\text { Polytechnic } \\
\text { Lecturer }\end{array}$ & $\begin{array}{l}\text { Teaching welding at Malaysian polytechnics is about 10 years old } \\
\text { and has worked with Continental Sime tire in welding field for } \\
\text { about 10 years. }\end{array}$ \\
\hline
\end{tabular}

Assessing the validity of the module content was made using the questionnaire of the contents of the module which required the assessor to provide the answer in the form of likert five-point scale namely: (1) strongly disagree, (2) disagree, (3) disapprove, (4) agree and 5) Strongly agree. The data were analyzed using the computation of the validity of the module content proposed by Tuckman and Waheed (1981). Tuckman and Waheed (1981) in Sidek and Jamaludin (2012) stated that expert judgments that exceed the $70 \%$ coefficient value have good authenticity and have mastered a high level of achievement. Modules with high content of validity will result in the achievement of the objectives that researchers want to measure (Md Noor et al., 2016). The formula for score assessment is as follows:

$$
\frac{\text { Expert Score Amount }}{\text { Maximum Score }} \times 100 \%=\text { The achievement of the validity of the Content }
$$

A set of validated module content questionnaires from Russell (1974) was built to get the overall content validity of the TIG Welding Training Module. According to Russel (1974), the module's content validity item has five things, namely; (i) meeting the target population; (ii) the module implementation method is appropriate; (iii) the time allocated to carry out the module is sufficient; 
INTERNATIONAL JOURNAL OF ACADEMIC RESEARCH IN BUSINESS AND SOCIAL SCIENCES

Vol. 8, No. 11, Nov, 2018, E-ISSN: 2222-6990 (C) 2018 HRMARS

(iv) the module successfully enhances student achievement in the targeted aspect; and ( $v$ ) the module succeeds in changing the attitude of the student towards a more brilliant.

\section{Results and Discussion}

The findings of the validity of the module consist of the overall content validity of the TIG Welding Training Modules based on the modifications of the Russell module module validity question (1974). As a result of four expert assessments, the value of the content validity of the TIG Welding Training Module can be seen in Table 2 below:

Table 2: Content Validity Overall by item for the TIG Welding Training Module

\begin{tabular}{|c|c|c|c|c|c|c|}
\hline \multirow[b]{2}{*}{ Item } & \multicolumn{4}{|c|}{ Content Expert } & \multirow[b]{2}{*}{ Average } & \multirow{2}{*}{$\begin{array}{l}\text { Expert } \\
\text { view }\end{array}$} \\
\hline & 1 & 2 & 3 & 4 & & \\
\hline $\begin{array}{l}\text { The contents of this Module correspond to } \\
\text { the academic level of the student }\end{array}$ & 100 & 100 & 100 & 80 & 95 & Accepted \\
\hline $\begin{array}{l}\text { The contents of this Module are } \\
\text { implemented perfectly }\end{array}$ & 100 & 80 & 100 & 60 & 85 & Accepted \\
\hline $\begin{array}{l}\text { The content of this module corresponds to } \\
\text { the time allocated }\end{array}$ & 80 & 100 & 100 & 60 & 85 & Accepted \\
\hline $\begin{array}{l}\text { This module will be able to nurture } \\
\text { teamwork, critical thinking and } \\
\text { communication skills among polytechnic } \\
\text { students }\end{array}$ & 80 & 100 & 100 & 80 & 90 & Accepted \\
\hline $\begin{array}{l}\text { The contents of this Module can provide } \\
\text { an understanding of the concept of TIG } \\
\text { welding to students more effectively }\end{array}$ & 100 & 100 & 100 & 80 & 95 & Accepted \\
\hline
\end{tabular}

Based on Table 2, the overall percentages for each item in the questionnaire are more than $90 \%$. The researcher found that the lowest percentage was 90 percent for two and three items. While the highest percentages of the highest content are 95 percent for the first and fifth items i.e. content this shows that the validity of the content of the TIG Welding Training Modules is to achieve a high level of performance achievement and can be adopted.

For this study, the two specialist verification methods were conducted, namely; a) validity in terms of constituent division (sessions) and substructures (activity in session), and b) content validation.

Table 3: The value of session validity and activity of TIG Welding Training Modules based on expert panel evaluation 
INTERNATIONAL JOURNAL OF ACADEMIC RESEARCH IN BUSINESS AND SOCIAL SCIENCES

Vol. 8, No. 11, Nov, 2018, E-ISSN: 2222-6990 (C) 2018 HRMARS

\begin{tabular}{|c|c|c|c|c|c|c|}
\hline \multirow[b]{2}{*}{ Sub Modules } & \multicolumn{4}{|c|}{ Content Expert } & \multirow[b]{2}{*}{ Average } & \multirow{2}{*}{$\begin{array}{l}\text { Expert } \\
\text { views }\end{array}$} \\
\hline & 1 & 2 & 3 & 4 & & \\
\hline Muka depan & 100 & 80 & 60 & 60 & 75 & Accepted \\
\hline Borang Pendaftaran Kumpalan Projek & 100 & 80 & 80 & 60 & 80 & Accepted \\
\hline \multicolumn{7}{|l|}{ Bab 1 Modul } \\
\hline 1.0 Pengenalan Modul & 80 & 100 & 100 & 80 & 90 & Accepted \\
\hline 1.1 Matlamat Modul & 80 & 100 & 100 & 80 & 90 & Accepted \\
\hline 1.2 Objektif & 100 & 100 & 80 & 80 & 90 & Accepted \\
\hline 1.3 Kerangka Konseptual modul & 100 & 100 & 60 & 80 & 85 & Accepted \\
\hline 1.4 Teori Pembelajaran & 80 & 100 & 60 & 80 & 80 & Accepted \\
\hline \multicolumn{7}{|l|}{ Bab 2 Pembelajaran Berasaskan Projek (PBP) } \\
\hline 2.0 Pengenalan PBP & 100 & 100 & 100 & 80 & 95 & Accepted \\
\hline 2.1 Ciri-ciri PBP & 100 & 100 & 100 & 80 & 95 & Accepted \\
\hline 2.2 Kelebihan PBP & 100 & 100 & 100 & 80 & 95 & Accepted \\
\hline \multicolumn{7}{|l|}{ Bab 3 Kimpalan TIG } \\
\hline 3.0 Pengenalan TIG & 100 & 100 & 100 & 80 & 95 & Accepted \\
\hline 3.1 Prinsip asas kimpalan TIG & 100 & 100 & 100 & 80 & 95 & Accepted \\
\hline 3.2 Mesin Kimpalan & 100 & 100 & 100 & 80 & 95 & Accepted \\
\hline 3.3 Elektrod & 80 & 80 & 100 & 80 & 85 & Accepted \\
\hline 3.4 Rod Penambah & 100 & 100 & 100 & 80 & 95 & Accepted \\
\hline 3.5 Gas Pelindung & 100 & 100 & 100 & 80 & 95 & Accepted \\
\hline 3.6 Kelebihan dan Kelemahan Kimpalan TIG & 100 & 100 & 100 & 80 & 95 & Accepted \\
\hline 3.7 Aksesori Kimpalan TIG & 80 & 100 & 100 & 80 & 90 & Accepted \\
\hline 3.8 Langkah- langkah keselamatan & 100 & 100 & 100 & 80 & 95 & Accepted \\
\hline 3.9 Penilaian Kemahiran kimpalan asas TIG & 100 & 100 & 100 & 80 & 95 & Accepted \\
\hline \multicolumn{7}{|l|}{ Bab 4 Latihan Sambungan asas kimpalan TIG } \\
\hline 4.0 Pengenalan & 100 & 100 & 100 & 80 & 95 & Accepted \\
\hline 4.1 Jenis Sambungan & 80 & 100 & 100 & 80 & 90 & Accepted \\
\hline 4.2 Latihan Kimpalan & 80 & 100 & 100 & 80 & 90 & Accepted \\
\hline 4.3 Skema permarkahan sambungan & 100 & 100 & 100 & 60 & 90 & Accepted \\
\hline 4.4 Skor Markah Kimpalan Asas TIG & 80 & 80 & 100 & 60 & 80 & Accepted \\
\hline \multicolumn{7}{|l|}{ Bab 5 Projek Kimpalan TIG } \\
\hline 5.0 Pengenalan & 100 & 100 & 100 & 80 & 95 & Accepted \\
\hline 5.1 Pernyataan Masalah & 100 & 100 & 100 & 80 & 95 & Accepted \\
\hline 5.2 Mengumpul Matlumat & 80 & 100 & 100 & 80 & 90 & Accepted \\
\hline 5.3 Menjana Idea & 80 & 80 & 100 & 80 & 85 & Accepted \\
\hline 5.4 Memilih lakaran & 100 & 100 & 100 & 80 & 95 & Accepted \\
\hline 5.5 Kenal pasti alatan dan bahan & 100 & 100 & 100 & 80 & 95 & Accepted \\
\hline 5.6 Langkah kimpalan & 100 & 100 & 100 & 80 & 95 & Accepted \\
\hline 5.7 Persembahan & 80 & 100 & 100 & 80 & 90 & Accepted \\
\hline 5.8 Kesimpulan & 100 & 100 & 100 & 80 & 95 & Accepted \\
\hline 5.9 Penilaian hasil kimpalan & 80 & 100 & 100 & 80 & 90 & Accepted \\
\hline 5.10 Skema Permarkahan & 100 & 100 & 100 & 60 & 90 & Accepted \\
\hline 5.11 Skor keseluruhan & 100 & 100 & 100 & 60 & 90 & Accepted \\
\hline Bab 6 Refleksi Kendiri & 100 & 100 & 100 & 80 & 95 & Accepted \\
\hline Overall average & & & & & & Accepted \\
\hline
\end{tabular}


INTERNATIONAL JOURNAL OF ACADEMIC RESEARCH IN BUSINESS AND SOCIAL SCIENCES Vol. 8, No. 11, Nov, 2018, E-ISSN: 2222-6990 @ 2018 HRMARS

Table 3 shows the percentage of 38 chapters evaluated in eight batch sessions conducted. The minimum percentage is 75 for chapters "muka depan", while the maximum percentage is 95 for the whole chapter. Therefore, based on the overall analysis of the percentage value is 90.92 above $70 \%$. This means that the level of validity of the TIG Welding Training Modules is reliable and has a strong consistency. In other words, the TIG Welding Training Modules are believed to be critical in improving critical thinking, teamwork and communication skills. The expert panel's validity value is above .06 i.e. the minimum value set for acceptance.

Table 4 showcases expert panel comments and improvements in content. Overall, the comments provided are very positive and greatly help researchers in modifying and improving the TIG Welding Training Module.

Table 4: Module Content Improvement Comment by Expert

\begin{tabular}{|c|c|}
\hline Expert & Improvement \\
\hline Expert 1 & $\begin{array}{l}\text { The type of electrode should be based on color } \\
>\text { Enter the electrode preparation step } \\
>\text { All images in modules that are not related to TIG welding are removed and } \\
\text { replaced with TIG welding } \\
>\text { The assessment routine is changed by removing the portion / impurity } \\
>\text { Picture of MIG connection changed to TIG }\end{array}$ \\
\hline Expert 2 & $\begin{array}{ll}\checkmark & \text { The frontal deposition should be changed } \\
\checkmark & \text { Insert TIG welding terminology } \\
\checkmark & \text { Insert the skim stick image of the AU / DCSP / DCRP welding machine type } \\
\checkmark & \text { Mark the torch part } \\
\checkmark & \text { Chapter } 4 \text { converts to TIG welding base connection training } \\
\checkmark & \text { State once the weakness of TIG welding } \\
\checkmark & \text { Change the problem statement to problematic stationery problem } \\
\checkmark & \text { Rubik formation level changed to penetration level } \\
\checkmark & \text { Diagram } 4 \text { and } 5 \text { are included in the electrodes section } \\
\checkmark & \text { The TIG weld connection image needs to be changed to more details }\end{array}$ \\
\hline Expert 3 & $\begin{array}{l}\text { - The front cover of the module should be clear and the image does not overlap } \\
\text { - } \\
\text { - } \quad \text { If you can link to TIG welding video } \\
\text { - } \quad \text { Insert a safety step in the self-reflection question }\end{array}$ \\
\hline Expert 4 & $\begin{array}{l}\text { The assessment is based on ISO } 5817 \text { and the project should be large- } \\
\text { scale } \\
\text { Enter matrix card, lecturer name and student class name }\end{array}$ \\
\hline
\end{tabular}

\section{Conclusion}

The TIG Welding Training Module was developed based on the design of Dick and Raiser in helping students to master the Subject (DJJ3032) of the Mechanical Workshop 3 effectively. Meanwhile, the 
future studies are suggested to build a Training Module for MIG welding or arc based on the Dick Dan Raiser Model design so that the achievement of Polytechnic students can be improved. Based on the findings of the validity of the module through the validity of the content by experts and assessors of the TIG Welding Training Module, it is found that the contents of this module encompass the appropriate module content, in accordance with population targets, conforming to the predetermined objectives as well as the time allocated. This coincides with Russel (1974) stating that the good and quality modules need to go beyond five things: i) meeting the population target, ii) the module can be implemented perfectly iii) in line with the time allocation, iv) improving the achievement of the aspect to be achieved and IV) can change a better attitude. The validity of this content has also been carried out by other researchers on their modules including Aliza (2016), Aziz (2010) and Jazimin (2011).

The researcher successfully constructed a specific and complete TIG Welding Training Module for Malaysia Polytechnic. The finding of the TIG Welding Training Modules shows that the contents of this module are valid and qualified to be adopted by Malaysian Polytechnic lecturers. Therefore, the researchers hope that this TIG Welding Training Module can be expanded and applied to assist teaching and learning in Malaysia Polytechnic especially in the field of TIG welding.

\section{Acknowledgement}

The authors wish to thank the Polytechnic Education Department of Higher Education Ministry of Malaysia for providing the data and Universiti Pendidikan Sultan Idris (UPSI) for funding this research under 2016-0139-107-01.

\section{Corresponding Author}

Md Kharul Bin Rakib, Department of Engineering Technology, Faculty of Technical and Vocational Education, Universiti Pendidikan Sultan Idris, 35900 Tanjung Malim, Malaysia,

Email: mdkharul87@gmail.com

\section{References}

Ahmad Mokhtar, M. (2006). Keberkesanan modul multimedia interaktif dalam meningkatkan kefahaman pelajar sekolah menengah terhadap topik pembahagian sel (Doctoral dissertation, Universiti Putra Malaysia).

Ahmad, J. (2002). Kesahan, Kebolehpercayaan dan Keberkesanan Modul Program Maju Diri

Atas Motivasi Pencapaian Dikalangan Pelajar Sekolah Menengah Negeri Selangor (Doctoral dissertation, Universiti Putra Malaysia).

Anastasia, A. \& Urbina, S. (1997). Psychological testing. Upper Saddle River: Prentice- Hall. Dick, W., \& Reiser, R. A. (1996). Instructional planning: A guide for teachers. Hoston: Allyn \& Bacon.

Honey, P. dan Mumford, A (1992). The Manual of Learning Style. (2nd ed.), United Kingdom: Peter Honey. 
INTERNATIONAL JOURNAL OF ACADEMIC RESEARCH IN BUSINESS AND SOCIAL SCIENCES

Vol. 8, No. 11, Nov, 2018, E-ISSN: 2222-6990 @ 2018 HRMARS

Md Noor, S. , Nurul Ain, M.D., \& Norazani, A. (2016). Kesahan dan kebolehpercayaan Modul I- Sc (Islamic Spiritual Counseling) ke atas pelajar bermasalah tingkah laku. International Journal of Islamic Thought, Vol. 9, 32-43.

Md Noor, S., Nurul Ain, M.D. \& Norazani, A. (2016). Kesahan dan kebolehpercayaan Modul I- Sc (Islamic Spiritual Counseling) ke atas pelajar bermasalah tingkah laku. International Journal of Islamic Thought, Vol. 9, 32-43.

Noah, S. M. (2005). Testing and evaluation in counseling: Theory and applications.

Noah, S. M., \& Ahmad, J. (2005). Module building. How to build exercise and academic module. Noraini, I. (2013). Penyelidikan dalam pendidikan (edisi kedua). Kuala Lumpur: McGraw Hill Education (Malaysia) Sdn. Bhd.

Othman, L. (2014). Penyelidikan kualitatif: Pengenalan kepada teori dan metode. Tanjong Malim, Perak: Penerbit Universiti Pendidikan Sultan Idris.

Pallant, J. (2007). SPSS survival manual, 3rd. Edition. McGrath Hill.

Razak, R. A., \& Rahman, M. A. (2017). Pembinaan media pengajaran berasaskan multimedia di kalangan guru ICTL. JuKu: Jurnal Kurikulum \& Pengajaran Asia Pasifik, 1(2), 20-31.

Rubani, S. N. K. (2016). Pembangunan dan keberkesanan modul perancahan berstruktur dalam pembelajaran berasaskan projek terhadap pengetahuan dan kemahiran bagi projek mesin larik pelajar politeknik (Doctoral dissertation, Universiti Sains Malaysia).

Rusell, J. D. (1974). Modular instruction: A guide to the design, selection, utilization and evaluation of modular materials. United States: Publishing Company.

Sidek, M.N, \& Jamaludin, A. (2005). Pembinaan Modul: Bagaimana Membina Modul Latihan dan Modul Akademik. Serdang: Penerbit Universiti Putra Malaysia.

Talib, M. A. \& Saud, M. S. (2011). Pembangunan perisian multimedia berpandukan PBK bagi topik asas kimpalan gas berteraskan teori beban kognitif (Doctoral dissertation, Universiti

Teknologi Malaysia).

Tuckman, B. W. \& Waheed, M. A. (1981). Evaluating an individualized science programmed for community college student. Journal of Research in Science Teaching, 18, 489-495. 